\title{
HYPOCHOLESTEROLEMIC EFFECT OF GARLIC POWDER IN LAYING HEN: LOW CHOLESTEROL EGG?
}

\author{
D.P. Rahardja, M. R. Hakim, W. Pakiding and V. S. Lestari \\ Faculty of Animal Agriculture, Hasanuddin University \\ Makassar, South Sulawesi - Indonesia \\ Corespondinge-mail : djoniprawira@yahoo.com
}

Received November 10, 2009 ; Accepted January 27, 2010

\begin{abstract}
Forty laying hens Hysex Brown consisting of 2 age groups (27 and 77 weeks of age) were used in the study to elucidate the hypocholesterolemic effect of garlic powder on egg production, serum and egg cholesterol. They were caged individually and fed diet containing 0 (control), 1, 2, and 4\% oven dried garlic powder for 4 periods of 4 weeks. The old hens consumed more food compared to those of the young one, while water consumption was in the reverse condition. The egg production indicated by the young hens fed dietary 1 and $2 \%$ garlic powder was significantly higher than those fed control diet. However, the old hens produced heavier eggs than those of the young hens, particularly when $1 \%$ garlic powder was supplemented. There was a closed relationship between serum and egg cholesterol, which reduced gradually with longer time the hens fed dietary garlic. The results clearly demonstrated that the laying hens fed dietary garlic powder up to $4 \%$ produced egg containing lower cholesterol (-34\%) compared to those fed control diet; The hypocholesterolemic effect of garlic powder is apparently higher in the old hen compared to that in the young hen.
\end{abstract}

Keywords : cholesterol, egg, garlic powder, hen, serum.

\section{INTRODUCTION}

Searching hypolipidemic agents in predominantly vegetarian human diets has yielded considerable information concerning the effects of plant materials on cholesterol metabolism in animal models. Studies on animals indicated that garlic (Allium sativum) has widely been used and reported to have hypocholesterolemic, hypolipidemic, and hypoglycemic properties. The magnitude of this action varies from 14\% lowering of serum cholesterol in human to a lowering of $80 \%$ in cholesterol-fed rabbits (Bardia et al., 1975; Bardia, 1981).

There are two bioactive components of garlic; S-allylcysteine sulfoxide (alliin) and diallyl disulfide-oxide (allicin) that were shown to lower cholesterol. Alliin is an odorless precursor of allicin which is resulted from catalyzing alliinase or alliin lyase, and the product is responsible for a characteristic smell of garlic (Yeh and Liu, 2001).

Sharma et al. (1979) reported that egg cholesterol was reduced by feeding 1 or $3 \%$ garlic powder for laying hens during 3 weeks; Sklan et al. (1992) reported that hepatic cholesterol concentration of laying hens was decreased when $2 \%$ garlic was fed for 2 weeks. Birrenkott et al.
(2000), however, reported that cholesterol concentrations of either yolk or serum of laying hens fed diet containing 3\% garlic powder for 8 months were not significantly affected. In many other studies, garlic was supplemented as the raw clove, steamed or fried cloves, as garlic pearls, powder, as juice or extract or as an essential oil. Such effects might explain some of the inconsistencies in the results of various studies of different garlic products.

The present study was designed to elucidate hypocholesterolemic effects of using garlic powder in a diet of laying hens on production performance and cholesterol content of eggs.

\section{MATERIALS AND METHODS}

The experiment was arranged as a completely randomized design using 40 laying hens of Hysex brown; they were placed randomly in individual cages having water and food vessels. The experiment was split into 2 age groups of 20 hens (27 and 77 weeks old at the commencement of the experiment); Each group consisted of 4 treatments and 5 hens as replication. The treatments were 0 (control), 1, 2 and $4 \%$ garlic 
powder supplementation of basal diet. The experiment was conducted for 4 periods of 4 weeks. In accordance to the standard procedures of AOAC (1980), nutrient contents of basal diet were $91 \%$ dry matter, $17 \%$ protein, $5.1 \%$ Fat, 2.3 $\%$ fiber, and $2800 \mathrm{kcal}$ energy $/ \mathrm{kg}$; whereas garlic powder contained $12.97 \%$ crude protein, $2.11 \%$ ether extract, $28.45 \%$ crude fiber, and $2.55 \%$ ash on dry matter basis.

Food and water were provided ad libitum, and their intakes were measured daily. Garlic bulbs were purchased from a certain shop of a traditional market in Makassar. There was no information about the origin and harvesting time of garlic purchased. Fresh garlic bulbs were peeled and cut into thin pieces. Then, it was subsequently spread on a hot air oven tray at 55$60^{\circ} \mathrm{C}$. Drying process was continued for $20-24 \mathrm{~h}$ to ensure the appropriate consistency for grinding to make a powder. Diets were prepared in the following day and were stored at room temperature for a maximum of 1 week.

Daily feed and water intakes, and egg production of individual hens were recorded; Hen day egg production (\%) was calculated weekly. In addition to the samples before treatments, blood and egg samples were collected consistently from the same 3 hens of each treatment at the end of every period. Blood was withdrawn from the wing vein in the morning before feeding, and the serum samples were directly send to the laboratory for cholesterol content analysis spectrophotometrically using commercial kit. Egg yolk was extracted by adding $15 \mathrm{ml}$ of chloroformmethanol $(2: 1 \mathrm{v} / \mathrm{v})$ to one gram of yolk placed in a centrifuge tube. Then, the mixture was blended on a vortex and allowed to extract within $12 \mathrm{~h}$. Cholesterol concentration of the extracted yolk was determined spectrophotometrically using commercial kit as the serum cholesterol determination.

Statistical analysis of results was performed by 2 ways analysis of variance ( 4 garlic levels x 2 age groups) with one factor as repeated measure. When the F test indicated a significant effect, the differences between the mean values were analyzed by the procedures of Duncan's multiple range test (Wilkinson, 1996).

\section{RESULTS}

Feed intake (Table 1) of the hens fed dietary garlic powder was significantly higher than those fed control diet, and this is particularly showed by the old hen group, whereas there was no significant effect on the young hens. Fluctuation of feed intakes up to the $4^{\text {th }}$ period of the experiment was not significant, either for different levels of garlic powder supplementation or different age groups of the hen.

As well as feed intake, water intakes (Table 1) of the hens fed dietary garlic powder were significantly higher than those fed control diet, but the young hens consumed more water than the old one. Water intake was significantly increased from the level in the $1^{\text {st }}$ period to the $2^{\text {nd }}$ period, but there was no further increase up to the $4^{\text {th }}$ period, either for different levels of garlic powder supplementation or different ages of the hen.

Egg production expressed as percentage of hen day production (\% HD) (Table 2 ) of the hens fed dietary garlic was significantly higher than those fed control diet, which were particularly indicated by the young hen group fed $2 \%$ of garlic supplementation; Egg weights (g/egg) (Table 2) of the hens fed dietary garlic powder were significantly heavier than those fed control diet, but these eggs were particularly produced by the old hen group with $1 \%$ of garlic powder supplementation.

Serum cholesterol concentrations of the hen fed control diet were not significantly altered by continuing the experiment up to the $4^{\text {th }}$ period, and the fluctuation was about $4.5 \%$ of pretreatment level. It suggests that this fluctuation in the concentration of serum cholesterol was a normal condition.

Serum cholesterol concentration of the hens decreased with the increasing level of garlic powder supplementation, and the decrease was continued with longer time of supplementation; different ages of the hens also indicated the same responses on garlic powder supplementation.

There was a closed relationship between serum cholesterol concentration and cholesterol content in egg. The present result indicated that egg cholesterol contents produced by the hens fed dietary garlic were significantly reduced compared to those fed control diet even so with the pretreatment condition, and apparently the hypocholesterolemic effect of garlic on egg cholesterol was more potential in the old hen group than the young one.

\section{DISCUSSION}

Considerable research has been conducted to develop and to produce egg which has low 
Table 1. Feed and Water Intakes of Laying Hens Hysex Brown Fed Dietary Garlic Powder (g/ hen/d)

\begin{tabular}{|c|c|c|c|c|c|c|}
\hline \multirow{2}{*}{\multicolumn{2}{|c|}{ Treatment }} & \multicolumn{4}{|c|}{ Period } & \multirow{2}{*}{ Mean } \\
\hline & & \multirow[t]{2}{*}{ I } & \multirow{2}{*}{$\begin{array}{l}\text { II } \\
\text { Feed intak }\end{array}$} & \multirow{2}{*}{$\begin{array}{c}\text { III } \\
\text { (g/hen/d) }\end{array}$} & \multirow[t]{2}{*}{ IV } & \\
\hline \multirow{5}{*}{ Garlic } & & & & & & \\
\hline & $0 \%$ & $119.88 \pm 16.45^{\mathrm{a}}$ & $124.36 \pm 27.47^{\mathrm{a}}$ & $123.98 . \pm 19.68^{\mathrm{a}}$ & $123.59 \pm 29.91^{\mathrm{a}}$ & $123.44 \pm 20.12^{\mathrm{a}}$ \\
\hline & $1 \%$ & $133.79 \pm 19.26^{b}$ & $128.80 \pm 16.60^{a b}$ & $139.21 \pm 13.56^{b}$ & $133.73 \pm 12.68^{b}$ & $133.88 \pm 15.58^{b}$ \\
\hline & $2 \%$ & $134.59 \pm 16.15^{b}$ & $132.79 \pm 20.74^{\mathrm{ab}}$ & $131.21 \pm 19.24^{\mathrm{ab}}$ & $133.41 \pm 12.86^{b}$ & $133.00 \pm 17.37^{b}$ \\
\hline & $4 \%$ & $131.95 \pm 17.06^{b}$ & $138.02 \pm 15.97^{b}$ & $136.91 \pm 16.10^{\mathrm{ab}}$ & $136.13 \pm 19.09^{b}$ & $135.75 \pm 16.59^{b}$ \\
\hline \multirow[t]{2}{*}{ Age } & old & $138.52 \pm 18.13^{b}$ & $142.61 \pm 22.04^{b}$ & $143.82 \pm 19.14^{b}$ & $146.60 \pm 22.22^{b}$ & $142.89 \pm 21.00^{b}$ \\
\hline & young & $128.26 \pm 16.72^{\mathrm{ab}}$ & $123.78 \pm 18.07^{\mathrm{a}}$ & $127.74 \pm 17.36^{\mathrm{a}}$ & $122.24 \pm 16.34^{\mathrm{a}}$ & $125.50 \pm 17.45^{a}$ \\
\hline \multicolumn{7}{|c|}{ Water intake $(\mathrm{g} / \mathrm{hen} / \mathrm{d})$} \\
\hline \multirow[t]{4}{*}{ Garlic } & $0 \%$ & $267.98 \pm 39.65^{\mathrm{a}}$ & $321.82 \pm 34.11^{\mathrm{ab}}$ & $315.86 \pm 48.94^{\mathrm{a}}$ & $332.73 \pm 25.60^{\mathrm{a}}$ & $309.60 \pm 44.33^{\mathrm{a}}$ \\
\hline & $1 \%$ & $278.47 \pm 32.80^{\mathrm{a}}$ & $340.05 \pm 27.72^{b}$ & $336.72 \pm 32.33^{b}$ & $337.84 \pm 23.08^{\mathrm{a}}$ & $323.27 \pm 38.43^{b}$ \\
\hline & $2 \%$ & $285.16 \pm 29.76^{\mathrm{a}}$ & $338.35 \pm 15.89^{b}$ & $329.55 \pm 17.39^{b}$ & $346.89 \pm 19.37^{\mathrm{a}}$ & $324.99 \pm 31.62^{b}$ \\
\hline & $4 \%$ & $293.88 \pm 40.79^{a}$ & $337.48 \pm 37.17^{b}$ & $327.43 \pm 31.54^{b}$ & $351.55 \pm 37.98^{\mathrm{a}}$ & $327.59 \pm 41.58^{b}$ \\
\hline \multirow[t]{2}{*}{ Age } & old & $272.18 \pm 34.45^{\mathrm{a}}$ & $309.41 \pm 32.47^{\mathrm{a}}$ & $304.10 \pm 33.08^{\mathrm{ab}}$ & $317.07 \pm 36.61^{\mathrm{a}}$ & $300.69 \pm 38.01^{\mathrm{a}}$ \\
\hline & young & $299.50 \pm 39.03^{\mathrm{a}}$ & $367.85 \pm 34.93^{\mathrm{b}}$ & $358.36 \pm 34.00^{\mathrm{b}}$ & $37379 \pm 35.41^{\mathrm{a}}$ & $349.88 \pm 44.23^{b}$ \\
\hline
\end{tabular}

Mean values within the same column with different superscript differ significantly $(\mathrm{P}<0.05)$

cholesterol content. In addition to the production performance of laying hens Hysex Brown, the present study was primarily focused on the hypothesis that cholesterol content of the egg can be reduced by feeding garlic powder to laying hens.

There are some factors affecting cholesterol content in the egg : genetic, diet, lay intensity, layer age, and medical treatment (Vorlova, 2001). Feed manipulation offers an economically sound approach to produce low cholesterol eggs, however careful pay attention to the balance and harmony with nature seem to be an important matter.

The results of the present study indicated that laying hens fed diet supplemented garlic powder resulted in an increased feed intake (Table 1), although the increase was not differ from the increasing levels of garlic supplementation. However, there was a tendency that the increasing garlic supplementation level up to 2 and $4 \%$ lowered the egg production performance of the hens compared to $1 \%$ supplementation.

Apparently, this egg production performance of the hens is attributable with the effect of garlic on lipid metabolism. It is clearly indicated that garlic has "cholesterol lowering effect" in both serum and egg yolk. Although the mechanism is not completely understood, Yeh and Liu (2001) indicated that the hypocholesterolemic action of garlic in part from inhibition of hepatic cholesterol synthesis. For in vitro study, Liu and Yeh (2000) revealed that water soluble organosulfur compounds, especially S-alliscystein (SAC), are potent inhibitors of cholesterol synthesis, and hence may be the mayor principles of garlic responsible for the reduction of blood cholesterol level. A similar hypocholesterolemic effect of garlic was observed previously in rat receiving aqueous extract raw garlic orally or intraperitoneally for a period of 4 weeks (Thomson et al., 2006). Hypocholesterolemic effects of garlic was also observed in laying hens (Mottaghitalab and Taraz, 2004; Sakine et al., 2006; Khan et al., 2007) and broiler (Quareshi et al., 1983; Nataamijaya and Zulbardi, 2001; Tollba and Hasan, 2003). Khan et al. (2007) showed that laying hens fed $8 \%$ dietary garlic powder for 6 weeks resulted in reducing blood cholesterol concentration by $74 \%$.

One suggestion of the mechanism is that garlic blocks HMG-CoA reductase, a key enzyme, which controls the rate of cholesterol synthesis in the liver (Quareshi et al., 1983; Liu and Yeh, 2002). However, it is a possibility that HMG-CoA reductase activity is down-regulated by isoprenoid and sterol intermediates, which can be expected that inhibition of a downstream cholesterolgenic 
Table 2. Egg Production Performance of Laying Hens Hysex Brown Fed Dietary Garlic Powder

\begin{tabular}{|c|c|c|c|c|c|c|}
\hline \multirow{2}{*}{\multicolumn{2}{|c|}{ Treatment }} & \multicolumn{4}{|c|}{ Period } & \multirow{2}{*}{ Mean } \\
\hline & & \multirow[t]{2}{*}{$\mathrm{I}$} & II & \multirow[t]{2}{*}{ III } & \multirow[t]{2}{*}{ IV } & \\
\hline \multicolumn{4}{|c|}{$\% \mathrm{HD}$} & & & \\
\hline \multirow[t]{4}{*}{ Garlic } & $0 \%$ & $74.76 \pm 16.57^{\mathrm{a}}$ & $77.26 \pm 13.09^{\mathrm{a}}$ & $75.00 \pm 7.49^{a}$ & $79.86 \pm 14.21^{\mathrm{a}}$ & $76.72 \pm 13.82^{\mathrm{a}}$ \\
\hline & $1 \%$ & $79.40 \pm 19.28 \mathrm{ab}$ & $85.72 \pm 9.37^{\mathrm{b}}$ & $82.14 \pm 8.75^{b}$ & $84.29 \pm 13.39^{b}$ & $82.75 \pm 14.42^{b}$ \\
\hline & $2 \%$ & $85.00 \pm 15.96^{b}$ & $88.22 \pm 8.26^{b}$ & $85.36 \pm 16.87^{b}$ & $83.57 \pm 23.88^{b}$ & $85.54 \pm 16.57^{b}$ \\
\hline & $4 \%$ & $75.71 \pm 14.07^{\mathrm{a}}$ & $79.29 \pm 25.30^{\mathrm{ab}}$ & $77.50 \pm 10.06^{\mathrm{a}}$ & $85.72 \pm 21.76^{b}$ & $79.55 \pm 20.24^{\mathrm{ab}}$ \\
\hline \multirow[t]{2}{*}{ Age } & old & $81.36 \pm 12.61^{\mathrm{a}}$ & $81.85 \pm 16.02^{\mathrm{a}}$ & $79.61 \pm 13.62^{a}$ & $77.11 \pm 8.18^{\mathrm{a}}$ & $79.98 \pm 15.25^{\mathrm{a}}$ \\
\hline & young & $78.72 \pm 12.89^{a}$ & $86.97 \pm 12.45^{b}$ & $83.73 \pm 4.84^{b}$ & $91.95 \pm 8.21^{\mathrm{b}}$ & $85.34 \pm 15.77^{b}$ \\
\hline \multicolumn{7}{|c|}{ Egg w eight (g / egg) } \\
\hline \multirow[t]{4}{*}{ Garlic } & $0 \%$ & $57.17 \pm 4.00^{a}$ & $56.14 \pm 4.24^{\mathrm{a}}$ & $57.26 \pm 4.00^{\mathrm{a}}$ & $58.13 \pm 4.88^{\mathrm{ab}}$ & $57.17 \pm 4.51^{a}$ \\
\hline & $1 \%$ & $59.72 \pm 3.84^{\mathrm{a}}$ & $60.18 \pm 3.23^{\mathrm{b}}$ & $61.43 \pm 3.53^{\mathrm{b}}$ & $61.52 \pm 3.86^{b}$ & $60.71 \pm 3.57^{b}$ \\
\hline & $2 \%$ & $57.52 \pm 5.49^{a}$ & $58.38 \pm 5.29^{a b}$ & $59.92 \pm 6.56^{b}$ & $59.33 \pm 4.87^{b}$ & $58.79 \pm 5.45^{\mathrm{ab}}$ \\
\hline & $4 \%$ & $57.20 \pm 3.18^{a}$ & $56.74 \pm 5.59^{a}$ & $59.15 \pm 3.28^{b}$ & $56.95 \pm 5.58^{a}$ & $57.51 \pm 4.49^{a}$ \\
\hline \multirow[t]{2}{*}{ Age } & old & $60.28 \pm 3.50^{\mathrm{b}}$ & $60.49 \pm 4.71^{b}$ & $61.74 \pm 4.76^{b}$ & $61.56 \pm 5.37^{b}$ & $61.02 \pm 4.64^{b}$ \\
\hline & young & $56.02 \pm 4.28^{\mathrm{a}}$ & $56.37 \pm 3.18^{\mathrm{a}}$ & $58.60 \pm 3.31^{\text {a }}$ & $56.98 \pm 3.18^{\text {a }}$ & $56.99 \pm 5.25^{\mathrm{a}}$ \\
\hline
\end{tabular}

Mean values within the same column having different superscript differ significantly $(\mathrm{P}<0.05)$

enzyme will result in the accumulation of one or more intermediates that may decrease HMG-CoA reductase activity. Recent studies using rat hepatoma cells (Song et al,. 2005; Singh and Poter, 2006) indicated that garlic inhibits $4 \alpha-$ methyl oxidase, resulted in accumulating linosterol and 4,4-dimethylzymosterol, which then strongly promoted the degradation of HMG-CoA reductase via an Insig-mediated pathway.

Reducing serum cholesterol concentrations in this study were 22, 33 and $38 \%$ of the pretreatment levels at the end of the $4^{\text {th }}$ period of the hens fed diet supplemented 1, 2, and $4 \%$ of garlic powder respectively. Apparently, reducing serum cholesterol concentration was consistently followed by decreasing of egg cholesterol content . The results from the present study demonstrated clearly that there was a closed relationship between serum cholesterol concentration and egg cholesterol. This relationship follows the equation :

$$
Y=1.743 X \text {----------- } R^{2}=0.994
$$

$(\mathrm{Y}=$ egg cholesterol, mg/egg; $\mathrm{X}=$ serum cholesterol concentration, $\mathrm{mg} / 100 \mathrm{ml} ; \mathrm{R}^{2}=$ determination coefficient)

Liver and ovary are the primary organ of cholesterol synthesis in laying hen. However, there is little, if any, direct transfer of ovariansynthesized cholesterol to develop oocyte (Elkin et al.,1999). Thus, the contribution of the ovaries on egg cholesterol levels are minimal. In contrast, cholesterol is readily transferred from the blood across the ovarian membranes to develop ova, and therefore most, if not all, egg yolk cholesterol originates from blood cholesterol.

Egg cholesterol content (Table 3) decreased with the increasing level of garlic powder supplementation. The results of the present study suggested that cholesterol contents of the egg produced by the hens fed diet containing garlic powder 1,2 and $4 \%$ up to the $4^{\text {th }}$ period were gradually reduced by 20,32 and $34 \%$. These results are in line of the finding of Khan et al. (2007) whose reported that feeding dietary garlic powder at 2, 6, and $8 \%$ for 6 weeks resulted in reducing egg yolk cholesterol concentrations $(\mathrm{mg} /$ g) by $5.7 ; 14.28$; and $23.5 \%$.

Apparently, this hypocholesterolemic effect of garlic powder was higher for the old hen group. This finding may be related to a higher potency of the old hen liver to synthesize cholesterol, transferred and accumulated into the ovary, as indicated by a higher serum cholesterol concentration. Jiang and Sim (1991) indicated that as the laying hens aged, the egg cholesterol content (mg/egg) increased. Shafey et al.(1998) 
Table 3. Total Cholesterol of Serum and Egg of Laying Hens Hysex Brown Fed Dietary Garlic Powder

\begin{tabular}{|c|c|c|c|c|c|c|c|}
\hline \multirow{2}{*}{\multicolumn{2}{|c|}{ Treatment }} & \multicolumn{5}{|c|}{ Period } & \multirow{2}{*}{$\begin{array}{c}\% \\
\text { change }\end{array}$} \\
\hline & & \multirow[t]{2}{*}{0} & I & II & \multirow[t]{2}{*}{ III } & \multirow[t]{2}{*}{ IV } & \\
\hline & & & Serun & Cholesterol (mg/ & & & \\
\hline \multirow[t]{4}{*}{ Garlic } & $0 \%$ & $175.33 \pm 4.74^{\mathrm{a}}$ & $177.26 \pm 6.87^{\mathrm{a}}$ & $172.35 \pm 8.73^{\mathrm{a}}$ & $172.24 \pm 4.61^{\mathrm{a}}$ & $174.86 \pm 5.77^{\mathrm{a}}$ & \pm 4.5 \\
\hline & $1 \%$ & $178.21 \pm 3.62^{\mathrm{a}}$ & $166.23 \pm 4.81^{\mathrm{b}}$ & $165.77 \pm 6.83^{b}$ & $151.28 \pm 5.74^{\mathrm{b}}$ & $137.44 \pm 8.55^{b}$ & -22.85 \\
\hline & $2 \%$ & $173.88 \pm 7.86^{\mathrm{a}}$ & $145.53 \pm 5.87^{\mathrm{b}}$ & $139,77 \pm 6.74^{\mathrm{d}}$ & $129.26 \pm 11.27^{\mathrm{cd}}$ & $115.49 \pm 4.69^{\mathrm{d}}$ & -33.19 \\
\hline & $4 \%$ & $175.29 \pm 8.92^{\mathrm{a}}$ & $140.68 \pm 4.76^{\mathrm{b}}$ & $129.65 \pm 5.99^{\mathrm{e}}$ & $110.27 \pm 9.41^{\mathrm{e}}$ & $108.22 \pm 3.75^{\mathrm{e}}$ & -38.26 \\
\hline \multirow[t]{3}{*}{ Age } & old & $189.26 \pm 2.49^{a}$ & $158.75 \pm 3.77^{\mathrm{c}}$ & $151.89 \pm 4.34^{\mathrm{c}}$ & $135.75 \pm 4.47^{\mathrm{c}}$ & $127.25 \pm 5.62^{\mathrm{c}}$ & -32.76 \\
\hline & young & $162.21 \pm 4.53^{\mathrm{a}}$ & $142.87 \pm 5.61^{\mathrm{b}}$ & $139.81 \pm 5.22^{\mathrm{d}}$ & $124.46 \pm 5.83^{\mathrm{d}}$ & $113.51 \pm 4.48^{\mathrm{f}}$ & -30.02 \\
\hline & \multicolumn{7}{|c|}{ Egg cholesterol (mg / egg) } \\
\hline \multirow[t]{4}{*}{ Garlic } & $0 \%$ & $310,75 \pm 2,86^{\mathrm{a}}$ & $328,51 \pm 0,99^{\text {a }}$ & $327,62 \pm 0,74^{\mathrm{a}}$ & $318,00 \pm 12,64^{\mathrm{a}}$ & $319,66 \pm 8,34$ a & \pm 5.4 \\
\hline & $1 \%$ & $314,75 \pm 12,06^{\mathrm{a}}$ & $267,80 \pm 10,36^{\mathrm{d}}$ & $256,46 \pm 2,20^{b}$ & $230,75 \pm 19,75^{b}$ & $204,69 \pm 4,18^{b}$ & $-20,05$ \\
\hline & $2 \%$ & $304,96 \pm 10,90^{\mathrm{a}}$ & $282,75 \pm 4,45^{\mathrm{b}}$ & $233,36 \pm 5,64^{c}$ & $212,79 \pm 7,27^{\mathrm{c}}$ & $185,71 \pm 4,72^{\text {cd }}$ & $-31,82$ \\
\hline & $4 \%$ & $308,89 \pm 8,46^{\mathrm{a}}$ & $275,52 \pm 7,37^{c}$ & $239,36 \pm 13,05^{\mathrm{c}}$ & $185,00 \pm 8,77^{\mathrm{d}}$ & $170,69 \pm 8,97 \mathrm{~d}$ & $-33,94$ \\
\hline \multirow[t]{2}{*}{ Age } & old & $312,16 \pm 6,81^{\mathrm{a}}$ & $283,97 \pm 10,61^{\mathrm{b}}$ & $250,57 \pm 7,13^{\mathrm{b}}$ & $210,92 \pm 6,90^{c}$ & $193,34 \pm 8,02^{c}$ & -38.06 \\
\hline & young & $297.52 \pm 5,93^{b}$ & $266,52 \pm 7,96^{\mathrm{d}}$ & $235,55 \pm 5,63^{\mathrm{c}}$ & $208,10 \pm 8,39^{c}$ & $190,65 \pm 8,25^{c}$ & -35.09 \\
\hline
\end{tabular}

Mean values within the same colomn having different supers cript differ significantly $(\mathrm{P}<0.05)$

reported that egg cholesterol content at 30 weeks of age was approximately $19 \%$ lower than that produced at 56 six weeks of age. However, it is a possibility that the old hens with a higher potency of cholesterol synthesis have a higher sensitivity to garlic powder treatment in depressing egg cholesterol content up to the same level as that of the young hens.

\section{CONCLUSION}

It can be concluded that the laying hens fed diet containing garlic powder up to $4 \%$ produced lower cholesterol egg by $34 \%$ compared to those fed control diet. This hypocholesterolemic effect may also be attributable with an increased egg production (\% HD and egg weight) when 1 or $2 \%$ of garlic powder was added. Additionally, the hypocholesterolemic effect of garlic powder is higher in the old laying hen.

\section{ACKNOWLEDGMENTS}

The financial support of the National Strategic Research of Directorate General of Higher Education, National Education Department of Indonesia is gratefully acknowledged by the authors.

\section{REFERENCES}

Association of Official Analytical Chemists. 1985. Official Methods of Analysis. $16^{\text {th }}$ ed. Association of Official Analytical Chemists, Washington, DC.

Bardia, A. 1981. Effect of garlic on blood lipids in patient with coronary heart disease.

Am.J.Clin.Nutr. 34: 2400-2103

Bardia, A., S.K. Arora, L.K. Kothari, R.C. Jala, B.S. Rathore, A.S. Rathore, M.K.Dube and $\mathrm{N}$, Bhu. 1975. The prospective actional essentials of onion and garlic in cholesterol fed rabbit. Atherosclerosis, 22: $103-109$.

Birrenkott, G., G.E. Brokenfelt, M. Owens and E. Halpin. 2000. Yolk and blood cholesterol levels and organoleptic assessment of egg from hens fed a garlic supplemented diet (abstract). Poult.Sci. 77: 75

Elkin, R.G., Z. Yan, Y. Zhong, S.S. Donkin, K.K. Buhma, J.A. Story, J.J. Turek, R.E.Porter Jr, M. Anderson, R. Homan and R.S. Newton, 1999. Select 3-hydroxy-3-methylglutarylcoenzym A reductase inhibitors vary in their ability to reduce egg yolk cholesterol levels in laying hens trough alteration of hepatic cholesterol biosynthesis and plasma VLDL composition. J.Nutr. 129: 1010-1019.

Jiang, Z.R. and J.S. Sim. 1991. Egg cholesterol values in relation to the age of laying hens 
and to egg and yolk weights. Poult. Sci. 78: 1838-1841.

Khan, S.H., R. Sardar and A, Anjum. 2007. Effects of dietary garlic on performance and serum and egg cholesterol concentration in laying hens. Asian J.Poult.Sci. 1: 22-27

Liu, L. and Y.Y. Yeh, 2000. Inhibition of cholesterol biosynthesis by organosulfur compounds derived from garlic. Lipids 35 : 197-203.

Mottaghitalab, M. and Z. Taraz. 2004. Garlic powder as serum and egg yolk cholesterol lowering agent. J.Poult.Sci. 41: 50-57

Nataamijaya, A.G. dan M. Zulbadri. 2001. Pengaruh Penambahan Bawang Putih (Allium Sativum L) terhadap Kinerja Karkas dan Jeroan Broiler. UNSOED Purwokerto, Edisi khusus. Februari. P. 121-126.

Qureshi, A.A., Z.Z. Din, N. Abuirmeileh, W.C. Burger, Y.Ahmad and C.E. Elson. 1983. Suppression of avian hepatic lipid metabolism by solvent extracts of garlic: impact on serum lipids. J. Nutr. 113: 17461755.

Shafey, T.M., J.G.Dingle, and M.W. McDonald. 1998. The relationship between egg yolk cholesterol, egg production and age of the hen in three Australian layer strains. J. Agric.Sci.King Saud Univ. 10: 33-41

Sakine, Y., E .E. Onbaşılar, Z. Reisli and Y. Suzan. 2006. Effect of garlic powder on the performance, egg traits and blood parameters of laying hens. J.Clin.Pathol. 86: 1336-1339

Sharma,R.K., R.A. Singh, R.N. Pal and C.K. Aggarwal. 1979. Cholesterol contents of chicken eggs as affected by feeding garlic, sarpagandha and nicotinic acid. Haryana
Agric.J.Res. 9: 263-265.

Singh, D.K., and T.D. Poter. 2006. Inhibition of sterol $4 a$-methyl oxidase Is the principal mechanism by which garlic decreases cholesterol synthesis. J. Nutr. 136: 759S$764 \mathrm{~S}$.

Sklan, D., Y.N. Burner and H.D. Rabinowitch. 1992. The effect of dietary onion and garlic on hepatic lipid concentration and activity of antioxidative enzymes in chicks. J.Nutr.Biochem. 3: 322-325.

Song, B.L., N.B. Javitt and R.A. DeBose-Boyd. 2005. Insig-mediated degradation of $\mathrm{HMG}$ CoA reductase stimulated by lanosterol, an intermediate in the synthesis of cholesterol. Cell Metab. 1: 179-189.

Thomson, T., K.K. Al-Qattan, T. Bordia and M. Ali. 2006. Including garlic in the diet may help lower blood glucose, cholesterol, and triglycerides. J.Nutr. 136: 800S-802S.

Tollba, A.A.H. and M.S.H. Hasan. 2003. Using some natural additives to improve physiological and productive performance of broiler chicks under high temperature conditions Black cumin (Nigella Sativa) or garlic (Allium Sativum).Poult.Sci. 23: 327340

Vorlova, L., E. Sieglova, R. Karpiskova and V. Kopriva. 2001. Cholesterol content in eggs during the laying period. Acta Vet.Brno. 70: 387-390

Wilkinson, L. 1996. "SYSTAT 6 for Windows" Statistics, SPSS Inc., USA.

Yeh, Y.Y. and L. Liu 2001. Cholesterol-Lowering effect of garlic extracts and organosulfur compounds: human and animal studies. J. Nutr. 131: 989S-993S. 